\title{
Effects of Boron and Molybdenum on the Yield of Chickpea
}

\author{
N.C. SHIL ${ }^{1 *}$, S. NOOR ${ }^{2}$ AND M.A. HOSSAIN ${ }^{3}$ \\ ${ }^{1 \& 2}$ Soil Science Division, Bangladesh Agricultural Research Institute, Gazipur, Bangladesh \\ ${ }^{3}$ Regional Agricultural Research Station, Bangladesh Agricultural Research Institute, Jessore, Bangladesh
}

\begin{abstract}
Field experiments on chickpea (cv. BARI Chola-5) were carried out in Calcareous Dark Grey Floodplain Soil under AEZ 11 at Jessore and Non Calcareous Grey Floodplain Soil under AEZ 13 at Rahmatpur during the rabi season of 2001-2002 and 2002-2003. The objective was to find out the optimum dose of boron and molybdenum for yield maximization. Four levels each of boron (0, 1, 2 and $2.5 \mathrm{~kg} / \mathrm{ha}$ ) and molybdenum (0,1, 1.5 and $2 \mathrm{~kg} / \mathrm{ha}$ ) along with a blanket dose of $N_{20} P_{25} K_{35} S_{20}$ $\mathrm{Zn}_{2} \mathrm{~kg} / \mathrm{ha}$ \& cowdung $5 \mathrm{t} / \mathrm{ha}$ were applied in this study. The combination of $B_{2.5} \mathrm{Mo}_{1.5} \mathrm{~kg} / \mathrm{ha}$ and $B_{2.5}$ $\mathrm{Mo}_{1} \mathrm{~kg} / \mathrm{ha}$ produced significantly higher yield in both the years of study at Jessore and Rahmatpur, respectively. The said treatments produced the highest mean yields of 2.10 and 1.49 t/ha for Jessore and Rahmatpur, respectively, which was around 53\% higher over control $\left(B_{0} M_{0}\right)$. The combined application of both boron and molybdenum were found superior to their single application even though boron played major role in augmenting the yield. However, from the regression analysis, the optimum treatment combination was calculated as $B_{2.34} M_{1.44} \mathrm{~kg} / \mathrm{ha}$ for Jessore and $B_{2.20} \mathrm{Mo}_{1.29} \mathrm{~kg} / \mathrm{ha}$ for Rahmatpur.
\end{abstract}

Key words: Boron, molybdenum, chickpea, yield, flood plain soil.

\section{INTRODUCTION}

Chickpea (Cicer arietinum L.), commonly known as gram, is a major pulse crop in Bangladesh stands $5^{\text {th }}$ in respect of area $(13,915 \mathrm{ha})$ and production $(10,380$ ton) among the pulse crop (BBS 2004). The average yield of chickpea is low (745 kg/ha) and almost stagnant over the years in Bangladesh (BBS 2004) while in the neighboring country like Mayanmer the average yield increased from 660 to $1004 \mathrm{~kg} / \mathrm{ha}$ in the recent years (ICRISAT 2003). The soils of different parts of Bangladesh are more or less deficient in boron and molybdenum, which causes poor yield of chickpea (Bhuiyan et al. 1997). However, there is a great possibility to increase its production by cultivating HYV with balanced fertilization.

Micronutrients play an important role in increasing yield of pulses and oilseed legumes through their effects on the plant itself and on the nitrogen fixing symbiotic process. The deficiency of these nutrients has been very pronounced under multiple cropping systems due to excess removal by HYV of crops and hence their exogenous supplies are urgently required. Molybdenum is required for the formation of the nitrate reductase enzyme and in the legume it plays an additional role in symbiotic nitrogen fixation. The nitrogen fixing enzyme, nitrogenase is composed of molybdenum

\footnotetext{
* Corresponding author: Senior Scientific Officer, Soil Science Division, BARI, Gazipur 1701. Mobile: 01718201499.

E-mail: nirmal_shil@yahoo.com

(C) 2006 School of Agriculture and Rural Development, Bangladesh Open University, All rights reserved.
} 
and iron and without adequate quantities of these elements, nitrogen fixation can't occur. Boron is very important in cell division and in pod and seed formation. Boron ranks third place among micronutrients in its concentration in seed and stem as well as its total amount after zinc (Robinson 1973). The critical level of boron with reference to crops in general was reported to be 0.15 to 0.20 ppm depending on soil types (BARC 2005). Effects of molybdenum and boron on different grain legumes have been reported by many scientists (Bhuiyan et al. 1998; Verma et al. 1988; Tiwari et al. 1989; Zaman et al. 1996 etc.).

The seed yield of green gram was highest with a combination of $5 \mathrm{~kg}$ borax/ha in combination with $2 \mathrm{~kg} / \mathrm{ha}$ sodium molybdate (Saha et al. 1996). Again, Bharti et al. (2002) reported that mean seed yield of chickpea increased with the application of boron @ $2.5 \mathrm{~kg} / \mathrm{ha}$. Islam (2005) observed that seed yield of chickpea (cv. BARI chola 5) increased significantly due to application of 1 to 1.5 $\mathrm{kg} \mathrm{B} / \mathrm{ha}$. In these contexts, application of boron and molybdenum in addition to essential major elements along with a maintenance dose of cowdung has gaining practical significance for boosting up the yield of chickpea. The present study was therefore, undertaken (i) to evaluate the response of boron and molybdenum on the yield of chickpea and (ii) to find out a suitable dose of boron and molybdenum for the maximization of yield.

\section{MATERIALS AND METHODS}

The experiment was conducted simultaneously in Calcareous Brown Floodplain Soil at RARS, Jessore and in Non Calcareous Grey Floodplain Soil at RARS, Rahmatpur during the rabi season of 2001-2002 and 2002-2003. The initial soil samples of the experimental fields were collected and analyzed following standard methods in the laboratory and are presented in Table 1.

Table 1. Fertility status of initial soil sample of the experimental field at RARS, Jessore and Rahmatpur

\begin{tabular}{|c|c|c|c|c|c|c|c|c|c|c|c|c|c|}
\hline \multirow{2}{*}{ Location } & \multirow{2}{*}{$\mathrm{pH}$} & \multirow{2}{*}{$\begin{array}{l}\text { OM } \\
(\%)\end{array}$} & \multirow{2}{*}{$\begin{array}{c}\text { Total N } \\
\%\end{array}$} & $\mathrm{Ca}$ & Mg & $\mathbf{K}$ & $\mathbf{P}$ & $s$ & $\mathrm{Cu}$ & $\mathrm{Fe}$ & $\mathrm{Mn}$ & $\mathrm{Zn}$ & B \\
\hline & & & & \multicolumn{3}{|c|}{ meq/100 gm } & \multicolumn{7}{|c|}{ g/gm } \\
\hline Jessore & 7.2 & 1.3 & 0.08 & 12.6 & 2.5 & 0.23 & 8 & 11 & 3 & 25 & 4 & 3 & 0.25 \\
\hline Rahmatpur & 6.7 & 1.4 & 0.07 & 10.8 & 3.5 & 0.14 & 13 & 16 & 7 & 85 & 6 & 2 & 0.30 \\
\hline $\begin{array}{l}\text { Critical } \\
\text { level }\end{array}$ & - & - & 0.12 & 2.0 & 0.5 & 0.2 & 14 & 14 & 1 & 10 & 1 & 2 & 0.20 \\
\hline $\begin{array}{l}\text { Inter- } \\
\text { pretation }\end{array}$ & $\mathrm{N}^{*}$ & Low & $\begin{array}{l}\text { Very } \\
\text { low }\end{array}$ & High & High & Low & $\begin{array}{l}\text { Very } \\
\text { low- } \\
\text { low }\end{array}$ & Low & $\begin{array}{l}\text { Opti- } \\
\text { mum- } \\
\text { High }\end{array}$ & $\begin{array}{l}\text { High- } \\
\text { very } \\
\text { high }\end{array}$ & High & Low & Low \\
\hline
\end{tabular}

* $N=$ Neutral

There were 16 treatment combinations comprising 4 levels each of molybdenum $(0,1,1.5,2 \mathrm{~kg} / \mathrm{ha})$ and boron $(0,1,2,2.5 \mathrm{~kg} / \mathrm{ha})$. A blanket dose of $\mathrm{N}_{20} \mathrm{P}_{25} \mathrm{~K}_{35} \mathrm{~S}_{20} \mathrm{Zn}_{2} \mathrm{~kg} / \mathrm{ha}$ \& cowdung $5 \mathrm{t} / \mathrm{ha}$ also incorporated with the treatments. The treatments were arranged in a randomized block design with 3 replications. The unit plot size was $3 \mathrm{~m} \times 5 \mathrm{~m}$. The tested variety was BARI Chola-5. All fertilizers and cowdung were applied at the time of final land preparation. Boron and molybdenum were applied as boric acid and sodium molybdate, respectively. Seeds were sown in lines maintaining a spacing of $30 \mathrm{~cm} \times 10 \mathrm{~cm}$ and using a seed rate of $35 \mathrm{~kg} / \mathrm{ha}$ at the $1^{\text {st }}$ week of December 2001 and last week of November for 2002 respectively. Intercultural operations and plant protection measures were done to keep the plant healthy. Crop was harvested at its maturity. Data was recorded for plant height, plant population, number of pots/plant, 100-seed weight and seed yield and was statically analyzed using IRRISTAT Package. 
Table 2a. Yield and yield attributes of chickpea as influenced by boron and molybdenum fertilization at Jessore during 2001-2002 and 2002-2003

\begin{tabular}{|c|c|c|c|c|c|c|c|c|c|c|c|c|}
\hline \multicolumn{3}{|c|}{ Treatment } & \multicolumn{2}{|c|}{ Plant height $(\mathrm{cm})$} & \multicolumn{2}{|c|}{ Pods/ plant (no.) } & \multicolumn{2}{|c|}{100 seed weight $(\mathrm{g})$} & \multicolumn{3}{|c|}{ Seed yield (t/ha) } & \multirow{3}{*}{$\begin{array}{c}\text { \% increase } \\
\text { in yield } \\
\text { over } \\
\text { control } \\
\left(\mathrm{B}_{0} \mathrm{Mo}_{0}\right)\end{array}$} \\
\hline \multirow[b]{2}{*}{ Code } & $\mathrm{B}$ & Mo & \multirow[b]{2}{*}{ 2001-02 } & \multirow[b]{2}{*}{$2002-03$} & \multirow[b]{2}{*}{ 2001-02 } & \multirow[b]{2}{*}{ 2002-03 } & \multirow[b]{2}{*}{ 2001-02 } & \multirow[b]{2}{*}{ 2002-03 } & \multirow{2}{*}{$\begin{array}{l}2001- \\
2002\end{array}$} & \multirow[b]{2}{*}{$\begin{array}{l}2002- \\
2003\end{array}$} & \multirow{2}{*}{ Mean } & \\
\hline & (kg/l & /ha) & & & & & & & & & & \\
\hline $\mathrm{T}_{1}$ & 0 & 0 & $0.6 \mathrm{~b}$ & $51.1 \mathrm{j}$ & $56.3 \mathrm{~d}$ & $63 \mathrm{~g}$ & 13.1 & 12.8 & $1.38 \mathrm{~g}$ & $1.35 \mathrm{f}$ & 1.37 & - \\
\hline $\mathrm{T}_{2}$ & 1 & 0 & $52.4 \mathrm{ab}$ & $52.8 \mathrm{~h}$ & $62.4 \mathrm{a}-\mathrm{d}$ & 69 & & 12 & $1.59 \mathrm{c}-\mathrm{g}$ & $1.62 \mathrm{de}$ & 1.61 & 17.5 \\
\hline $\mathrm{T}_{3}$ & 2 & 0 & $52.7 \mathrm{ab}$ & $53.6 \mathrm{~g}$ & $67.0 \mathrm{abc}$ & $74 \mathrm{c}$ & & & $1.69 \mathrm{~b}-\mathrm{f}$ & $1.74 \mathrm{~cd}$ & & \\
\hline $\mathrm{T}_{4}$ & 2.5 & 0 & $53.0 \mathrm{ab}$ & $54.5 \mathrm{f}$ & $65.4 \mathrm{abc}$ & $73 d$ & 13.3 & 13.0 & $1.74 \mathrm{a}-\mathrm{f}$ & $1.77 \mathrm{~cd}$ & 1.76 & 28.5 \\
\hline$T_{5}$ & 0 & 1 & 5 & $1.4 \mathrm{j}$ & $60.2 \mathrm{~cd}$ & 67 & & & $1.46 \mathrm{fg}$ & 1.42 ef & 1.44 & \\
\hline $\mathrm{T}_{6}$ & 1 & 1 & $54.5 \mathrm{ab}$ & $55.5 \mathrm{e}$ & $68.9 \mathrm{ab}$ & $77 \mathrm{~b}$ & & & $1.80 \mathrm{a}-\mathrm{e}$ & $1.83 \mathrm{bcd}$ & 1.82 & 32.8 \\
\hline $\mathrm{T}_{7}$ & 2 & 1 & $54.2 \mathrm{ab}$ & $55.5 \mathrm{e}$ & $66.7 \mathrm{abc}$ & $75 c$ & 13.6 & 13.1 & $1.89 \mathrm{ab}$ & $1.89 \mathrm{bc}$ & 1.89 & 38.0 \\
\hline $\mathrm{T}_{8}$ & 2.5 & 1 & $55.5 \mathrm{ab}$ & $56.6 \mathrm{~d}$ & $67.2 \mathrm{abc}$ & $4 \mathrm{c}$ & 3.2 & 13.1 & $1.93 \mathrm{ab}$ & 1.92 bc & 1.93 & 40.9 \\
\hline $\mathrm{T}_{9}$ & 0 & 1.5 & & & & & & & $1.52 \mathrm{efg}$ & 1.46 ef & 1.49 & \\
\hline $\mathrm{T}_{10}$ & 1 & 1.5 & $56.2 \mathrm{ab}$ & $57.1 \mathrm{~cd}$ & $64.6 \mathrm{abc}$ & $73 d$ & 13 & 13.0 & $1.78 \mathrm{a}-\mathrm{e}$ & $1.80 \mathrm{~cd}$ & 1.79 & 30.7 \\
\hline $\mathrm{T}_{11}$ & 2 & 1.5 & $56.4 \mathrm{ab}$ & $57.3 \mathrm{c}$ & $70.5 \mathrm{a}$ & $78 \mathrm{a}$ & 13.1 & 13.2 & $1.94 \mathrm{ab}$ & $2.07 \mathrm{ab}$ & 2.00 & 46.0 \\
\hline $\mathrm{T}_{12}$ & 2.5 & 1.5 & & & & & & & $2.03 \mathrm{a}$ & $2.16 \mathrm{a}$ & 2.10 & 53.3 \\
\hline $\mathrm{T}_{13}$ & 0 & 2 & 50.9 & $51.8 \mathrm{i}$ & $9.5 \mathrm{~cd}$ & 68 ef & 13.2 & 12.8 & $1.56 \mathrm{~d}-\mathrm{g}$ & 1.40 ef & 1.48 & 8.0 \\
\hline $\mathrm{T}_{14}$ & 1 & 2 & $56.2 \mathrm{ab}$ & $57.4 \mathrm{c}$ & $66.3 \mathrm{abc}$ & $74 \mathrm{c}$ & 13.1 & 12.9 & $1.83 \mathrm{a}-\mathrm{d}$ & $1.78 \mathrm{~cd}$ & 1.81 & 32.0 \\
\hline $\mathrm{T}_{15}$ & 2 & 2 & & & & & & 13.2 & $1.87 \mathrm{abc}$ & $1.85 \mathrm{bcd}$ & 1.86 & 35.8 \\
\hline $\mathrm{T}_{16}$ & 2.5 & 2 & 54.8 & & & 72 & 13 & 13.0 & $1.89 \mathrm{ab}$ & $1.97 \mathrm{abc}$ & 1.93 & 40.9 \\
\hline \multicolumn{3}{|c|}{ CV (\%) } & 7.7 & 5.6 & 6.7 & 6.9 & 2.3 & 1.4 & 8.3 & 7.3 & & \\
\hline
\end{tabular}

Blanket dose : $\mathrm{N}_{20} \mathrm{P}_{25} \mathrm{~K}_{35} \mathrm{~S}_{20} \mathrm{Zn}_{2} \mathrm{~kg} / \mathrm{ha}$ \& cowdung 5 t/ha

Figures in a column having same letter(s) do not differ significantly at $5 \%$ level by DMRT

Table $2 \mathrm{~b}$. Yield and yield attributes of chickpea as influenced by boron and molybdenum fertilization at Rahmatpur during 2001-2002 and 2002-2003

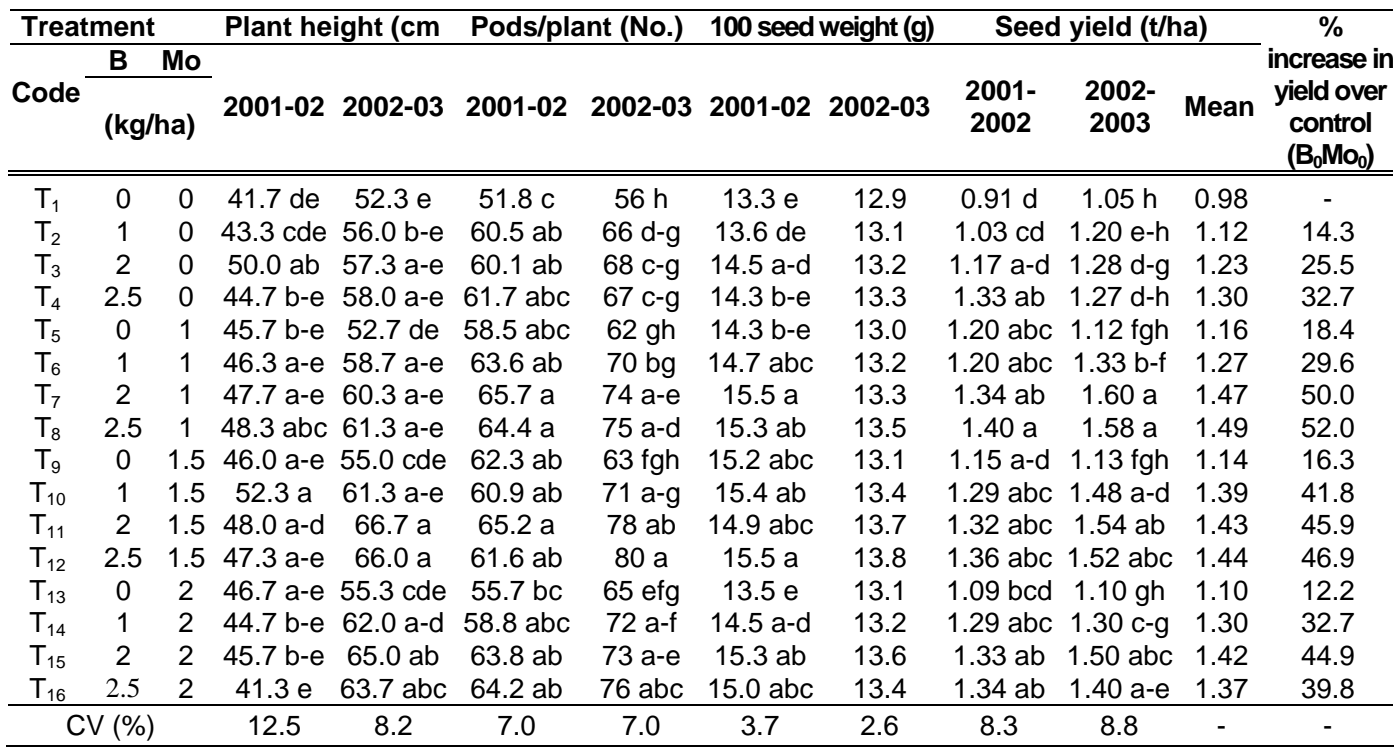

Figures in a column having same letter(s) do not differ significantly at $5 \%$ level by DMRT

Blanket dose: $\mathrm{N}_{20} \mathrm{P}_{25} \mathrm{~K}_{35} \mathrm{~S}_{20} \mathrm{Zn}_{2} \mathrm{~kg} / \mathrm{ha}$ \& cowdung 5 t/ha 
N.C. Shil et al.

\section{RESULTS AND DISCUSSION}

\section{Effect of Boron and Molybdenum}

Chickpea responded significantly due to application of boron and molybdenum in both the years and locations. It was found that yield and yield components like plant height, number of pods/plant, 100 -seed weight were significantly influenced due to boron and molybdenum fertilization (Tables $2 a$ \& $2 \mathrm{~b})$. In Jessore, the highest yield (2.16 t/ha) was obtained with $\mathrm{T}_{12}\left(\mathrm{~B}_{2.5} \mathrm{Mo}_{1.5} \mathrm{~kg} / \mathrm{ha}\right)$, which was statistically identical to $T_{11}\left(B_{2} M_{1.5}\right)$ and $T_{16}\left(B_{2.5} M_{2}\right)$ but significantly higher over rest of the treatments. Boron principally contributed to the yield and the crop performed better with subsequent higher doses up to $2.5 \mathrm{~kg} \mathrm{~B} / \mathrm{ha}$. On the other hand, the contribution of molybdenum to the yield was not so much prominent (5-9\% only). These findings revealed that boron alone played major role in augmenting the yield. However, the combined effect of boron and molybdenum was found superior to their single application contributing 32-53\% higher yield over control, which signifies their requirements for maximizing the yield. In Rahmatpur, the highest yield (1.60 t/ha) was obtained from the treatment $T_{7}\left(B_{2} M_{1} \mathrm{~kg} / \mathrm{ha}\right.$ ), which was significantly higher over $T_{1}$ (Bo Mo), $T_{6}$ $\left(B_{1} M_{1}\right), T_{14}\left(B_{1}, M_{2}\right)$ and single application of either boron or molybdenum but at par with rest of the treatments. The combined application of both molybdenum and boron was found superior than their single applications, which contributed to $30-50 \%$ yield increase over control. Significant role of boron and molybdenum on the yield of chickpea was reported by many scientists (Bhuiyan et al. 1998; Sakal et al. 1988; Verma et al. 1988 and Pal 1986).

The treatment, $T_{12}\left(B_{2.5} M_{1.5} \mathrm{~kg} / \mathrm{ha}\right)$ was found to be the best combination in both the years of study producing the highest mean yield (2.10 t/ha), which was $53 \%$ higher over control at Jessore while $\mathrm{T}_{8}\left(\mathrm{~B}_{2.5} \mathrm{Mo}_{1} \mathrm{~kg} / \mathrm{ha}\right)$ generated the highest mean yield $(1.49 \mathrm{t} / \mathrm{ha})$ at Rahmatpur contributing $52 \%$ higher yield over control. The response of the crop to different treatments showed more or less similar trend in both the years and locations. However, the effect was found more prominent in Calcareous Dark Grey Floodplain Soil at Jessore compared to Non- Calcareous Grey Floodplain Soil of Rahmatpur, which might be due to the differences in agro ecology, fertility status of the soil and management practices. Moreover, the yield recorded in the $2^{\text {nd }}$ year was found relatively higher than the $1^{\text {st }}$ year in both the study areas, which may be explained by the differences in climatic condition between the 2 years of study.

\section{Effect of boron}

Applied boron showed significant effect on the yield of chickpea both at Jessore and Rahmatpur in consecutive two years trials (Table 3). At Jessore, the highest yield (1.90 and 1.95 t/ha for $2001-$ 2002 and $2002-2003$, respectively) was obtained with $2.5 \mathrm{~kg} \mathrm{~B} / \mathrm{ha}$, which was statistically identical with immediate lower dose $(2.0 \mathrm{~kg} \mathrm{~B} / \mathrm{ha})$ but significantly higher over the lowest dose $(1.0 \mathrm{~kg} \mathrm{~B} / \mathrm{ha})$ and boron control. Similar trend of response was observed at Rahmatpur in the first year (20012002), while in the second year (2002-2003), the highest yield was obtained with moderate dose $(2.0 \mathrm{~kg} \mathrm{~B} / \mathrm{ha})$, which was statistically identical with higher dose $(2.5 \mathrm{~kg} \mathrm{~B} / \mathrm{ha})$ but significantly greater over rest of the boron doses (Table 3). However, yield obtained at Jessore with boron was $35-38 \%$ higher than that of Rahmatpur, which might be due to difference in agro-climatic condition and yield potentiality between the two regions.

Table 3. Mean effect of boron on the seed yield of chickpea at Jessore and Rahmatpur

\begin{tabular}{|c|c|c|c|c|c|c|c|c|}
\hline \multirow{2}{*}{$\begin{array}{l}\text { Levels of } \\
\text { boron } \\
(\mathrm{kg} / \mathrm{ha})\end{array}$} & \multicolumn{3}{|c|}{ Seed yield (t/ha) at Jessore } & \multirow{2}{*}{$\begin{array}{c}\% \text { increase } \\
\text { in yield over } \\
\text { control (B) }\end{array}$} & \multicolumn{3}{|c|}{ Seed yield (t/ha) at Rahmatpur } & \multirow{2}{*}{$\begin{array}{c}\% \text { increase } \\
\text { in yield over } \\
\text { control (B) }\end{array}$} \\
\hline & $\begin{array}{l}2001- \\
2002 \\
\end{array}$ & $\begin{array}{l}2002- \\
2003 \\
\end{array}$ & Mean & & $\begin{array}{l}2001- \\
2002\end{array}$ & $\begin{array}{l}2002- \\
2003\end{array}$ & Mean & \\
\hline 0 & $1.48 \mathrm{c}$ & $1.41 \mathrm{c}$ & 1.45 & 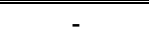 & $1.09 \mathrm{c}$ & $1.10 \mathrm{c}$ & 1.10 & 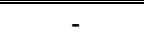 \\
\hline 1.0 & $1.75 \mathrm{~b}$ & $1.76 \mathrm{~b}$ & 1.76 & 21.4 & $1.24 \mathrm{~b}$ & $1.36 \mathrm{~b}$ & 1.30 & 18.2 \\
\hline 2.0 & $1.85 \mathrm{ab}$ & $1.89 \mathrm{a}$ & 1.87 & 29.0 & $1.29 \mathrm{ab}$ & $1.48 \mathrm{a}$ & 1.39 & 26.4 \\
\hline 2.5 & $1.90 \mathrm{a}$ & $1.95 \mathrm{a}$ & 1.93 & 33.1 & $1.36 \mathrm{a}$ & $1.44 \mathrm{ab}$ & 1.40 & 27.3 \\
\hline $\mathrm{CV}(\%)$ & 8.3 & 7.3 & - & - & 8.3 & 8.8 & - & - \\
\hline
\end{tabular}

Figures in a column having same letter(s) do not differ significantly at $5 \%$ level by LSD 
Regression analysis showed that the mean yield and applied boron fitted better with positive and quadratic response functions at both the locations (Figures $1 \& 2$ ). The optimum dose of boron was calculated form the quadratic response function as 2.58 and $2.39 \mathrm{~kg} / \mathrm{ha}$ for Jessore and Rahmatpur, respectively (Table 4). Using the said optimum dose, the maximum seed yield of 1.92 and 1.40 t/ha could be expected for Jessore and Rahmatpur, respectively (Table 4). However, the optimum economic dose of boron was calculated to be $2.34 \mathrm{~kg} \mathrm{~B} / \mathrm{ha}$ for Jessore and $2.20 \mathrm{~kg} / \mathrm{ha}$ for Rahmatpur. The use efficiency showed that each $1 \mathrm{~kg} \mathrm{~B}$ could produce 179 and $126 \mathrm{~kg} / \mathrm{ha}$ of seed yield up to the optimum level at Jessore and Rahmatpur, respectively. Beyond the said optimum dose, if $1 \mathrm{~kg} / \mathrm{ha}$ excess boron is applied then there is a risk of loosing 69 and $53 \mathrm{~kg} / \mathrm{ha}$ of seed yield for Jessore and Rahmatpur, respectively.

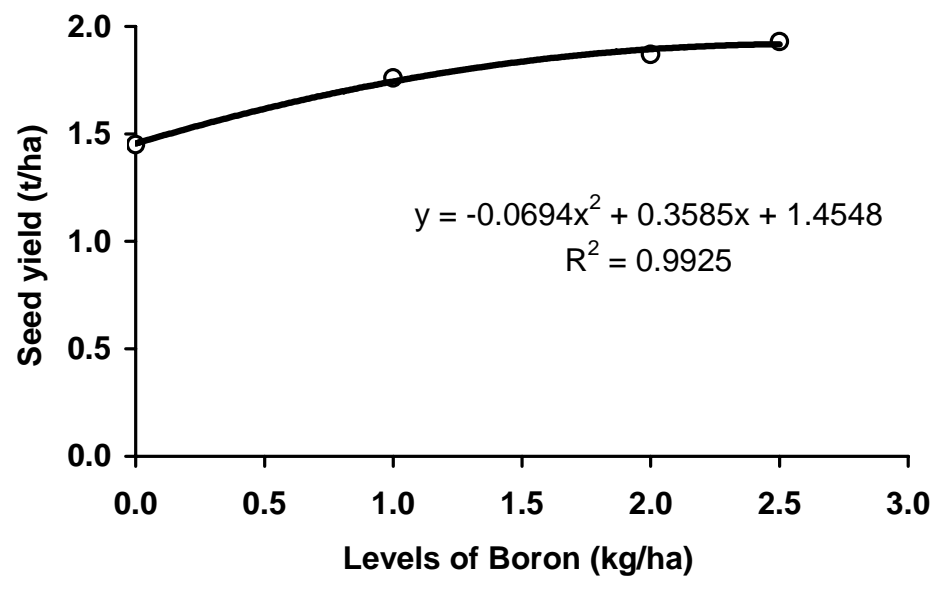

Fig 1. Response of Chickpea to Boron at Jessore

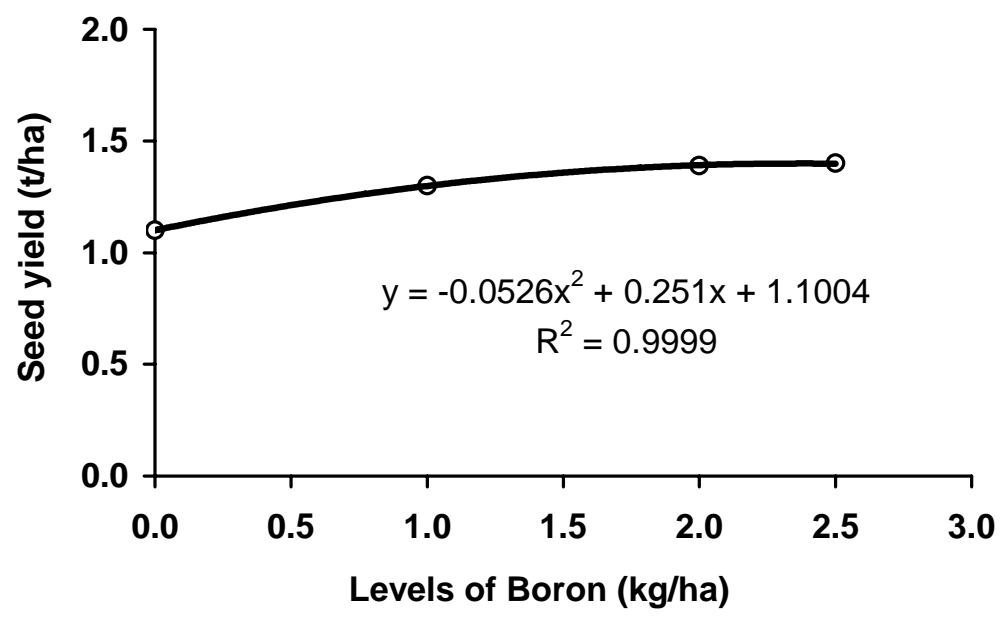

Fig 2. Response of Chickpea to Boron at Rahmatpur 
N.C. Shil et al.

Table 4. Response function of chickpea to boron for seed yield at Jessore and Rahmatpur

\begin{tabular}{|c|c|c|c|c|c|c|}
\hline $\begin{array}{l}\text { Regression } \\
\text { equation }\end{array}$ & $\begin{array}{l}\text { Co-efficient of } \\
\text { determination } \\
\qquad\left(R^{2}\right)\end{array}$ & $\begin{array}{l}\text { Optimum } \\
\text { dose } \\
\text { (kg/ha) }\end{array}$ & $\begin{array}{l}\text { Optimum } \\
\text { economic } \\
\text { dose }\end{array}$ & $\begin{array}{c}\text { Maximum } \\
\text { seed yield } \\
\text { (t/ha) for } \\
\text { optimum dose }\end{array}$ & $\begin{array}{l}\text { Production of } \\
\text { seed (kg/ha) } \\
\text { for } 1 \mathrm{~kg} \mathrm{~B} \mathrm{(use} \\
\text { efficiency) }\end{array}$ & $\begin{array}{l}\text { Beyond optimum } \\
\text { dose the reduction } \\
\text { of seed yield } \\
(\mathrm{kg} / \mathrm{ha} \text { ) for } 1 \mathrm{~kg} \mathrm{~B}\end{array}$ \\
\hline \multicolumn{7}{|l|}{ Jessore } \\
\hline $\begin{aligned} Y= & -0.0694 x^{2} \\
& +0.3585 x \\
& +1.4548\end{aligned}$ & 0.993 & 2.58 & 2.34 & 1.92 & 179 & 69 \\
\hline \multicolumn{7}{|l|}{ Rahmatpur } \\
\hline $\begin{aligned} Y= & -0.0526 x^{2} \\
& +0.251 x \\
& +1.1004\end{aligned}$ & 0.999 & 2.39 & 2.20 & 1.40 & 126 & 53 \\
\hline
\end{tabular}

\section{Effect of Molybdenum}

The yield of chickpea was found to increase progressively up to 1.5 and $1.0-1.5 \mathrm{~kg} \mathrm{Mo} / \mathrm{ha}$ at Jessore and Rahmatpur, respectively (Table 5). Significantly higher yield was recorded only over molybdenum control while the other levels produced identical results in both the years and locations. Apparently Jessore area needs more molybdenum than Rahmatpur area, which might be due to the higher yield potential of the crop of Jessore than Barisal. The highest mean yield (1.85 t/ha) was obtained with $1.5 \mathrm{~kg} \mathrm{Mo} / \mathrm{ha}$ at Jessore, which was $15 \%$ higher over control. However, at Rahmatpur, the highest mean yield (1.35 t/ha) was obtained with 1.0 and $1.5 \mathrm{~kg} \mathrm{Mo} / \mathrm{ha}$, which was $16 \%$ higher over control.

Table 5. Mean effect of molybdenum on the seed yield of chickpea at Jessore and Rahmatpur

\begin{tabular}{|c|c|c|c|c|c|c|c|c|}
\hline \multirow{2}{*}{$\begin{array}{l}\text { Levels of } \\
\text { molybdenum } \\
(\mathrm{kg} / \mathrm{ha})\end{array}$} & \multicolumn{3}{|c|}{ Seed yield (t/ha) at Jessore } & \multirow{2}{*}{$\begin{array}{l}\% \text { increase } \\
\text { in yield over } \\
\text { control (Mo) }\end{array}$} & \multicolumn{3}{|c|}{$\begin{array}{c}\text { Seed yield (t/ha) at } \\
\text { Rahmatpur }\end{array}$} & \multirow{2}{*}{$\begin{array}{l}\% \text { increase } \\
\text { in yield over } \\
\text { control (Mo) }\end{array}$} \\
\hline & $\begin{array}{l}2001- \\
2002 \\
\end{array}$ & $\begin{array}{l}2002- \\
2003 \\
\end{array}$ & Mean & & $\begin{array}{l}2001- \\
2002 \\
\end{array}$ & $\begin{array}{l}2002- \\
2003 \\
\end{array}$ & Mean & \\
\hline 0 & $1.60 \mathrm{~b}$ & $1.62 \mathrm{c}$ & 1.61 & - & $1.11 \mathrm{~b}$ & $1.20 \mathrm{~b}$ & 1.16 & - \\
\hline 1.0 & $1.77 \mathrm{a}$ & $1.77 \mathrm{ab}$ & 1.77 & 9.9 & $1.29 \mathrm{a}$ & $1.41 \mathrm{a}$ & 1.35 & 16.4 \\
\hline 1.5 & $1.82 \mathrm{a}$ & $1.87 \mathrm{a}$ & 1.85 & 14.9 & $1.28 \mathrm{a}$ & $1.42 \mathrm{a}$ & 1.35 & 16.4 \\
\hline 2.0 & $1.79 \mathrm{a}$ & $1.75 \mathrm{~b}$ & 1.77 & 9.9 & $1.26 \mathrm{a}$ & $1.33 \mathrm{a}$ & 1.30 & 12.1 \\
\hline $\mathrm{CV}(\%)$ & 8.3 & 7.3 & - & - & 8.3 & 8.8 & - & - \\
\hline
\end{tabular}

Figures in a column having same letter(s) do not differ significantly at $5 \%$ level by LSD

From regression analysis, a positive and quadratic relationship was found between seed yield and levels of molybdenum at both the locations (Figures $3 \& 4$ ). The optimum dose of molybdenum was calculated from the quadratic production function as $1.44 \& 1.29 \mathrm{~kg} \mathrm{Mo} / \mathrm{ha}$ for Jessore and Rahmatpur, respectively (Table 6). Using the same optimum dose, the maximum seed yield of 1.82 and $1.36 \mathrm{t} /$ ha could be expected for Jessore and Rahmatpur, respectively. However, the optimum dose of molybdenum may not be economic in terms of marginal benefit because molybdenum fertilizer is costly. In spite of this, molybdenum is very essentially required by the legume crops like chickpea for biological nitrogen fixation and without its proper supplement drastic yield reduction may happen in the long run. It appears from use efficiency that each $1 \mathrm{~kg}$ Mo could produce 146 and $135 \mathrm{~kg} / \mathrm{ha}$ of seed yield up to the optimum level at Jessore and Rahmatpur, respectively, Beyond the said optimum dose, if $1 \mathrm{~kg} / \mathrm{ha}$ excess molybdenum is applied, then there is a risk of loosing 102 and $118 \mathrm{~kg} / \mathrm{ha}$ seed yield for Jessore and Rahmatpur, respectively. 


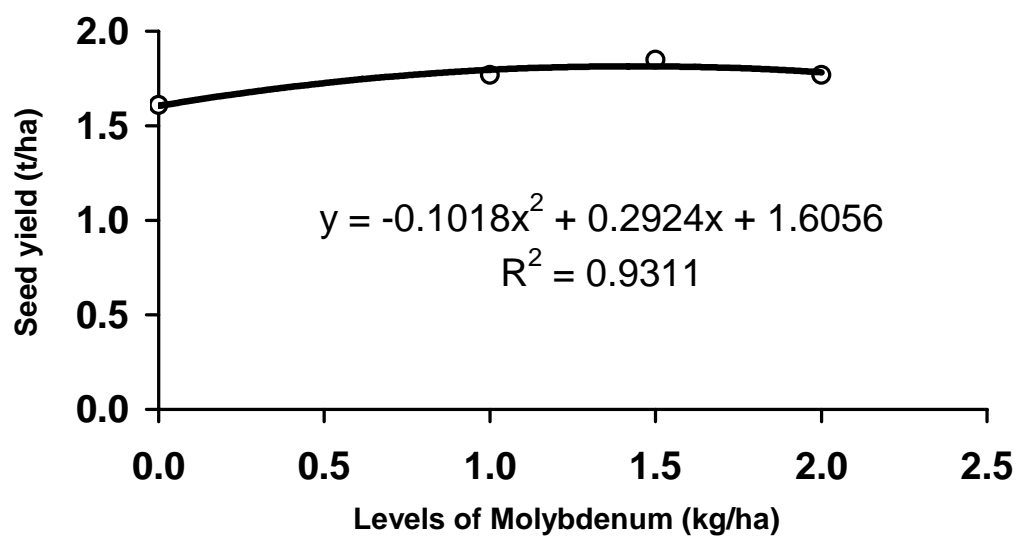

Fig. 3. Response of chikcpea to Molybdenum at Jessore

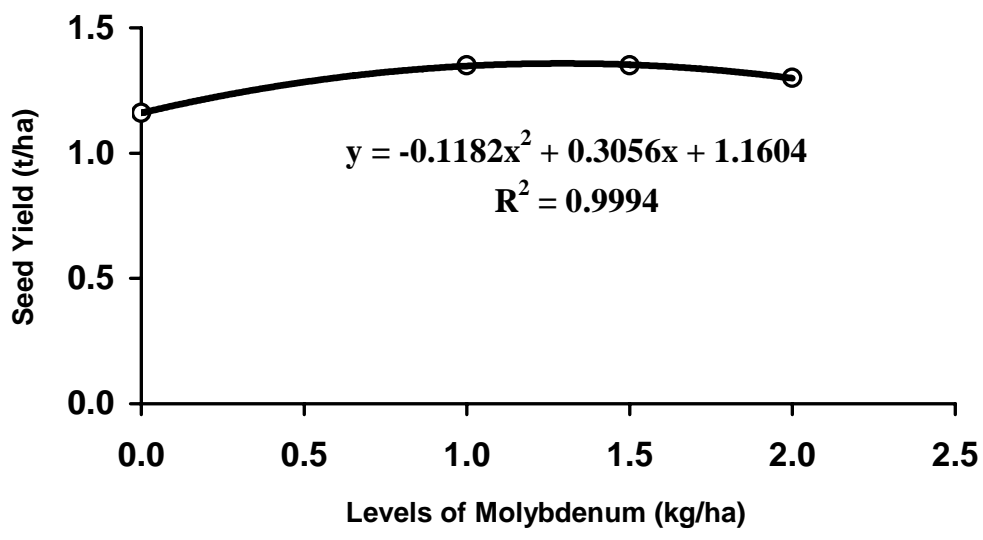

Fig. 4. Response of Chikcpea to Molybdenum at Rahmatpur

Table 6. Response function of chickpea to molybdenum for seed yield at Jessore and Rahmatpur

\begin{tabular}{|c|c|c|c|c|c|}
\hline $\begin{array}{l}\text { Regression } \\
\text { equation }\end{array}$ & $\begin{array}{l}\text { Co-efficient of } \\
\text { determination } \\
\qquad\left(R^{2}\right)\end{array}$ & $\begin{array}{c}\text { Optimum } \\
\text { dose (kg/ha) }\end{array}$ & $\begin{array}{l}\text { Maximum seed } \\
\text { yield (t/ha) for } \\
\text { optimum dose }\end{array}$ & $\begin{array}{l}\text { Production } \\
\text { of seed } \\
\text { (kg/ha) for } 1 \\
\mathrm{~kg} \mathrm{mg} \mathrm{(use} \\
\text { efficiency) }\end{array}$ & $\begin{array}{c}\text { Beyond optimum } \\
\text { dose the } \\
\text { reduction of seed } \\
\text { yield (kg/ha) for } 1 \\
\text { kg Mo } \\
\end{array}$ \\
\hline \multicolumn{6}{|l|}{ Jessore } \\
\hline $\begin{aligned} Y= & -0.1018 x^{2} \\
& +0.2924 x \\
& +1.6056\end{aligned}$ & 0.931 & 1.44 & 1.82 & 146 & 102 \\
\hline
\end{tabular}


N.C. Shil et al.

\begin{tabular}{|c|c|c|c|c|c|}
\hline $\begin{aligned} Y= & -0.1182 x^{2} \\
& +0.3056 x \\
& +1.1604\end{aligned}$ & 0.999 & 1.29 & 1.36 & 153 & 118 \\
\hline
\end{tabular}

\section{CONCLUSION}

It can be concluded from the above findings that the treatment combinations of $(2.5 \mathrm{~kg} \mathrm{~B} / \mathrm{ha} \mathrm{\&} 1.5$ $\mathrm{kg} \mathrm{Mo} / \mathrm{ha}$ ) and (2.5 kg B/ha \& $1 \mathrm{~kg} \mathrm{Mo} / \mathrm{ha})$ along with a blanket dose of $\mathrm{N}_{20} \mathrm{P}_{25} \mathrm{~K}_{35} \mathrm{~S}_{20} \mathrm{Zn}_{2} \mathrm{~kg} / \mathrm{ha}$ \& cowdung $5 \mathrm{t} /$ ha were found suitable for maximizing yield of chickpea in Calcareous Dark Grey Floodplain Soil under AEZ 11 at Jessore and Non Calcareous Grey Floodplain Soil under AEZ 13 at Rahmatpur, respectively. However, from the regression analysis the optimum treatment combinations appeared to be $\left(B_{2.58} M_{1.44} \mathrm{~kg} / \mathrm{ha}\right)$ for Jessore and $\left(B_{2.39} M_{1.29} \mathrm{~kg} / \mathrm{ha}\right)$ for Rahmatpur. The optimum economic dose of boron was found to be 2.34 and $2.20 \mathrm{~kg} / \mathrm{ha}$ for Jessore and Rahmatpur, respectively. Therefore, the above-mentioned package $\left(\mathrm{B}_{2.34} \mathrm{Mo}_{1.44} \mathrm{~kg} / \mathrm{ha}\right.$ for Jessore and $B_{2.20} \mathrm{Mo}_{1.29} \mathrm{~kg} / \mathrm{ha}$ for Rahmatpur) along with the said blanket dose of other fertilizer and manure may be recommended for yield sustainability and to maintain soil fertility.

\section{LITERATURE CITED}

BARC. 2005. Critical limits of nutrients in soils. In Fertilizer Recommendation Guide - 2005. Soil Publication No. 45. The Bangladesh Agricultural Research Council, Dhaka. p. 240.

BBS. 2004. Year Book of Agril. Statistics of Bangladesh. Bangladesh Bureau of Statistics, Ministry of Planning, Govt. of the Peoples Republic of Bangladesh, Dhaka.

Bharti, N., Murtaza, M. and Singh, A. P. 2002. Effect of boron Rhizobium relationship on yield, nitrogen and boron nutrition of chickpea. J. Res. Birsa Agric. Univ. 14(2), 175-179.

Bhuiyan, A. H., Khanam, D., Rahman, M. H. H and Hossain, A. K. M. 1997. Influence of Rhizobium inoculum, molybdenum and boron on Chickpea in Grey Terrace Soil of Bangladesh. Ann. Bangladesh Agric. 7: 119126.

Bhuiyan, M. A. H., Khanam, D. Khatun, M. R. and Hassan, M. S. 1998. Effect of molybdenum, boron and Rhizobium on nodulation, growth and yield of chickpea Bull. Inst. Trop. Agric. 21, 1-7.

CRISAT. 2003. In Annual Report . International Crops Research Institute for the Semi-Arid Tropics. Patancheru, Andrapradesh, India. p.12.

Slam, B. 2005. Requirement of boron for mustard, wheat and chickpea based cropping pattern. Unpublished [Ph.D. Thesis], Department of Soil Science, Bangladesh Agricultural University, Mymensingh. 124 pp.

Mishpa, S. K., Shrivastava, G. K., Pandey, D. and Tripathi, R. S. 2001. Optimization of chickpea production through nutrient management and growth regulators under rice based cropping system in vertisols. Anals, Agric. Res. 22(2), 299-301.

Pal, A. K. 1986. Interaction of Rhizobium inoculation with phosphate and molybdenum application on chickpea at rainfed condition. Environ. \& Ecol. 4, 642-647.

Robinson, R. G. 1973. Elemental composition and response to nitrogen of sunflower and corn. Agron J. 65: 318-320.

Saha, A., Mandal, B. K. and Mukhopadyay, P. 1996. Residual effect of boron and molybdenum on the yield of succeeding mungbean in summer. Indian Agriculturist. 40(1), 11-16.

Sakal, R., Sinha, R. B. and Singh, A. P. 1988. Effect of boron application on blackgram and chickpea production in calcareous soil. Fertilizer News. 33, 27-30.

Tiwari, V. N., Lehri, L. K. and Pathak, A. N. 1989. Rhizobium inoculation of legumes as influenced by phosphorus and molybdenum fertilization J. Indian Soc. Soil Sci. 37, 712-716.

Verma, L. P., Ram, P. C. and Maurya, B. R. 1988. Response of chickpea to phosphorus and molybdenum in alluvium of Eastern Uttar Pradesh. Inter chickpea Newsletter. 18, 31-33.

Zaman, A. K. M. M, Alam, M. S., Biswas, B. K., Roy, B. and Beg, A. H. 1996. Effect of B and Mo application on mungbean. Bangladesh J. Agril. Res. 21, 118-124. 